\title{
ASOSIASI RAMIN (Gonystylus bancanus (Miq.) Kurz) DENGAN JENIS DOMINAN DI IUPHHK-HA PT DIAMOND RAYA TIMBER, RIAU
}

\author{
Association of Ramin (Gonystylus bancanus (Miq.) Kurz) with Dominan Species in IUPHHK-HA \\ PT Diamond Raya Timber, Riau
}

Istomo $^{1^{*}}$ dan Ida Sufaidah ${ }^{2}$

(Diterima Agustus 2017/Disetujui Juni 2020)

\begin{abstract}
Ramin is one of slow growing spesies, have a medium until big measurement, have a silindris stem, high total reach 40-50 $m$ with DBH reach $120 \mathrm{~cm}$. The purpose of this research is to know association between ramin (Gonystylus bancanus (Miq.) Kurz) and dominan species in IUPHHK-HA PT Diamond Raya Timber, Riau. Vegetation analysis used combination method between strip and line compartment method. Result showed that no one of dominan species have association with Gonystylus bancanus in tree and pole level at IUPHHK-HA PT DRT. Although there is no species in pole level that have association with Gonystylus bancanus, but there is tendency that Gonystylus bancanus have positive association with Palaquium obovatum, Urandra scorpioides, Carallia brachiata, and have negative association with Artocarpus teysmanii and Eugenia sp. At tree level Gonystylus bancanus have a tendency that have positive association with Shorea uliginosa, Palaquium obovatum, Eugenia sp., Horsfieldia glabra, and have negative association with Aglaia rubiginosa and Mangifera foetida.
\end{abstract}

Keywords: Association, combination, dominan species, Gonystylus bancanus, growing spesies

\section{PENDAHULUAN}

Hutan gambut merupakan ekosistem yang unik dengan ciri selalu tergenang air, komposisi jenis pohon beranekaragam mulai dari sejenis sampai campuran, terdapat lapisan gambut pada lantai hutan, mempunyai perakaran yang khas, dan dapat tumbuh pada tanah yang bersifat masam (Asian Wetland Bureau dan Ditjen PHPA 1993). Jenis-jenis pohon penting yang tumbuh di hutan gambut antara lain ramin (Gonystylus bancanus), meranti batu (Shorea uliginosa), durian burung (Durio carinatus), geronggang (Cratoxylon arborescens), punak (Tetramerista glabra), dan tumih (Combretocarpus tetundatus).

Ramin dikenal sebagai salah satu jenis pohon utama penyusun hutan rawa gambut terutama yang mengalami genangan air secara periodik dan juga daerah yang tidak tergenang hingga ketinggian $100 \mathrm{~m}$ di atas permukaan laut. Ramin tergolong jenis pohon tumbuh lambat, berukuran sedang sampai besar, berbatang lurus silindris, tinggi total bisa mencapai $40-50 \mathrm{~m}$ dengan diameter batang setinggi dada mencapai $120 \mathrm{~cm}$. Permintaan pasar akan kayu ramin terus meningkat hingga mendorong penebangan dan eksploitasi secara besar-besaran. Awalnya ramin bukan merupakan jenis kayu yang sangat diminati seperti saat ini. Perdagangan kayu ramin terbatas untuk kebutuhan dalam negeri dan pasaran Asia terutama Jepang dan Taiwan. Dewasa ini, perdagangan

\footnotetext{
${ }^{1}$ Staf Pengajar Departemen Silvikultur, Fakultas

Kehutanan dan Lingkungan Institut Pertanian Bogor

* Penulis korespondensi:

e-mail: istomo19@gmail.com

2 Mahasiswa Departemen Silvikultur, Fakultas Kehutanan Institut Pertanian Bogor
}

kayu ramin telah meluas hingga di pasaran Eropa (Inggris, Italia, dan Jerman), Amerika, dan Australia (Suhartono dan Mardiastuti dalam Partomihardjo 2006). Akibat eksploitasi yang berlebihan, populasi ramin yang hanya berkembang di habitat rawa gambut terus menurun tajam. Beberapa wilayah hutan produksi daerah rawa gambut yang masih memiliki tegakan ramin adalah PT Diamond Raya Timber, PT Rokan Permai, PT Triomas FD (ketiganya merupakan anak perusahaan Uniseraya Group) dan PT Inhutani IV di kabupaten Indragiri Hilir (Partomihardjo 2006). Satu-satunya hutan produksi yang memiliki ijin untuk memproduksi ramin adalah PT Diamond Raya Timber. Menurut Istomo (2005) PT DRT memiliki ijin menebang ramin karena kuota raminnya masih memenuhi dan memiliki Sertifikat Pengelolaan Hutan Alam Lestari (SPHPL).

Menurunnya populasi ramin juga disebabkan oleh musim berbunga ramin yang tidak menentu dan informasi tentang biologi bunga ramin secara rinci termasuk sistem penyerbukan belum tersedia. Selain itu biji ramin dikenal cepat busuk serta memiliki viabilitas rendah (Partomihardjo 2006). Kondisi demikian telah menimbulkan kekhawatiran berbagai pihak akan ancaman kepunahan jenis tersebut. Sejak tahun 2004, jenis ramin masuk ke dalam kategori Appendix II CITES. Hal tersebut menunjukkan bahwa jenis ramin belum terancam punah tetapi akan terancam punah jika perdagangannya tidak diatur ketat. Melalui pembatasan perdagangan internasional dengan sistem CITES, penerapan sistem pengelolaan hutan lestari, budidaya dan pengkayaan ramin merupakan upaya penyelamatan ramin dari ancaman kepunahan.

Beberapa informasi penting dibutuhkan dalam pengoptimalan budidaya ramin, seperti asosiasi ramin dengan beberapa vegetasi dominan di hutan rawa 
gambut. Asosiasi merupakan hubungan ketertarikan untuk tumbuh bersama dalam suatu komunitas yang dapat bersifat positif, negatif, atau tidak berasosiasi. Asosiasi positif terjadi bila suatu jenis tumbuhan hadir bersamaan dengan jenis tumbuhan lainnya atau pasangan jenis terjadi lebih sering daripada yang diharapkan. Asosiasi negatif terjadi bila suatu jenis tumbuhan tidak hadir bersamaan dengan jenis tumbuhan lainnya atau pasangan jenis terjadi kurang daripada yang diharapkan (Kurniawan 2008). Tujuan penelitian ini adalah mengkaji asosiasi antara ramin (Gonystylus bancanus (Miq.) Kurz) dengan jenis dominan di IUPHHK-HA PT Diamond Raya Timber, Riau.

\section{METODE PENELITIAN}

\section{Waktu dan Tempat Penelitian}

Kegiatan penelitian ini dilaksanakan pada bulan April 2016 di areal Biodiversity Strip (areal yang digunakan untuk menjaga keanekaragaman) IUPHHKHA PT Diamond Raya Timber, Provinsi Riau.

\section{Alat dan Bahan Penelitian}

Alat-alat yang digunakan dalam penelitian ini adalah peta lokasi, pita ukur, phiband meter, Global Positioning System (GPS), kompas, tambang, patok, tally sheet, buku identifikasi tumbuhan, dan kamera digital. Bahan yang diamati dalam penelitian ini adalah Gonystylus bancanus dan beberapa vegetasi lain yang tumbuh di areal Biodiversity Strip PT Diamond Raya Timber. Pengolahan data dilakukan dengan menggunakan program Microsoft excel.

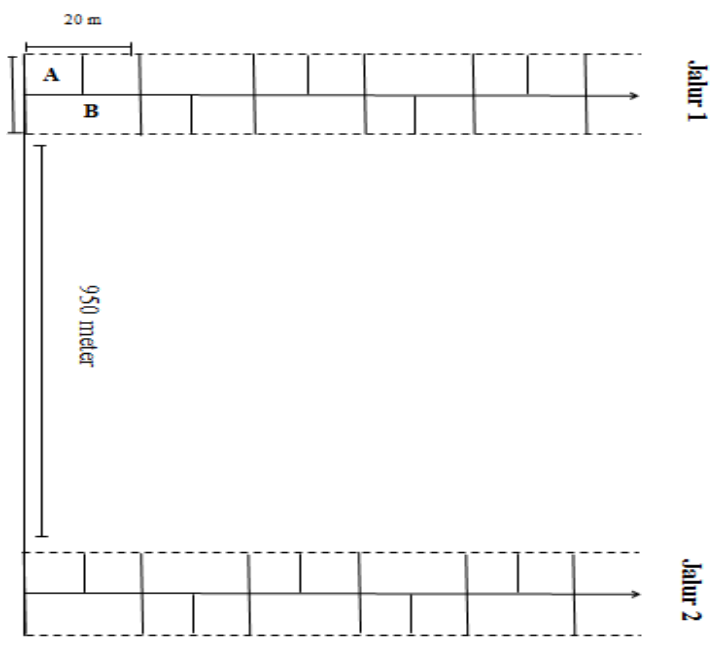

Gambar 1 Desain petak pengamatan (A) tingkat tiang $(10 \times 10 \mathrm{~m})$, dan $(\mathrm{B})$ tingkat pohon (20 x $20 \mathrm{~m})$

\section{Jenis Data yang Dikumpulkan}

Data yang dikumpulkan berupa data primer dan data sekunder. Data primer merupakan data yang langsung dikumpulkan di lapangan. Data primer yang diambil meliputi nama jenis, jumlah jenis, jumlah individu dan diameter setinggi dada (untuk tingkat tiang dan pohon). Data sekunder yang dikumpulkan berupa informasi terkait kondisi umum lapangan yang meliputi sejarah kawasan, letak, luas, kondisi tanah, topografi, iklim, kondisi vegetasi satwa, dan masyarakat sekitar kawasan hutan.

\section{Metode Pengumpulan Data}

Pengambilan data menggunakan metode kombinasi antara metode jalur dan garis berpetak (Indriyanto 2006). Setiap jalur pengamatan terdiri dari 5 petak berukuran 20 m x $20 \mathrm{~m}$ untuk mengukur vegetasi tingkat pohon (diameter setinggi dada $\geq 20 \mathrm{~cm}$ ) dan $10 \mathrm{~m} \times 10 \mathrm{~m}$ untuk vegetasi tingkat tiang (diameter setinggi dada $10-20$ $\mathrm{cm})$. Satu jalur mewakili satu biodiversity strip. Jalur yang digunakan sebanyak 6 jalur pada biodiversity strip tahun 2013 dan 2015 (Gambar 1).

\section{Analisis Data}

Analisis data dilakukan pada data hasil analisis vegetasi dan akan didapatkan indeks nilai penting dan asosiasi antara jenis ramin dengan jenis-jenis dominan pada lokasi penelitian.

\section{Indeks Nilai Penting (INP)}

Indeks Nilai Penting ini digunakan untuk menentukan dominansi suatu jenis terhadap jenis lain. Indeks Nilai Penting (INP) merupakan peenjumlahan dari Kerapatan Relatif (KR), Frekuensi Relatif (FR), dan Dominansi Relatif (DR) (Soerianegara dan Indrawan 1988).

Kerapatan

$$
=\frac{\text { Jumlah individu suatu jenis }}{\text { Luas petak contoh }} \text { ind/ha) }
$$

Kerapatan Relatif

$$
=\frac{\text { Kerapatan suatu jenis }}{\text { Kerapatan seluruh jenis }} \times 100 \%
$$

Frekuensi

$$
=\frac{\text { Jumlah plot ditemukan suatu jenis }}{\text { Jumlah seluruh plot }}
$$

Frekuensi Relatif

$$
=\frac{\text { Frekuensi suatu jenis }}{\text { Frekuensi seluruh jenis }} \times 100 \%
$$

Dominansi

$$
=\frac{\text { Jumlah LBDS suatu jenis }}{\text { Luas petak contoh }}\left(\mathrm{m}^{2} / \mathrm{ha}\right)
$$

Dominansi Relatif

$$
=\frac{\text { Dominansi suatu jenis }}{\text { Dominansi seluruh jenis }} \times 100 \%
$$

Indeks Nilai Penting (INP) $=\mathrm{KR}+\mathrm{FR}+\mathrm{DR}$ (untuk tingkat tiang dan pohon)

Tabel 1 Tabel kontingensi $2 \times 2$

\begin{tabular}{lllll}
\hline & & & & Jenis B \\
\cline { 2 - 5 } & & Ada & Tidak ada & Jumlah \\
\hline \multirow{2}{*}{ Jenis A } & Ada & $\mathrm{a}$ & $\mathrm{b}$ & $\mathrm{a}+\mathrm{b}$ \\
\cline { 2 - 5 } & Tidak ada & $\mathrm{c}$ & $\mathrm{d}$ & $\mathrm{c}+\mathrm{d}$ \\
\cline { 2 - 5 } & Jumlah & $\mathrm{a}+\mathrm{c}$ & $\mathrm{b}+\mathrm{d}$ & $\mathrm{N}=\mathrm{a}+\mathrm{b}+\mathrm{c}+\mathrm{d}$ \\
\hline
\end{tabular}

Keterangan: $\mathrm{a}=$ jumlah plot ditemukannya kedua jenis $(\mathrm{A}$ dan $\mathrm{B}), \mathrm{b}=$ jumlah plot ditemukannya jenis $\mathrm{A}, \mathrm{c}=$ jumlah plot ditemukannya jenis $\mathrm{B}, \mathrm{d}=$ jumlah plot yang tidak ditemukan jenis $\mathrm{A}$ maupun $\mathrm{B}, \mathrm{N}=$ jumlah plot. 


\section{Analisis asosiasi}

Analisis asosiasi antara jenis ramin dengan jenisjenis dominan dapat dilakukan dengan menggunakan Tabel Kontingensi 2x2. Bentuk Tabel Kontingensi 2x2 dapat dilihat pada Tabel 1.

Adanya kecenderungan untuk berasosiasi atau tidak dapat digunakan Chi-square Test dengan formulasi sebagai berikut: Chi-square hitung $=\frac{(|a b-b c|-N / 2)^{2} \mathrm{~N}}{(\mathrm{a}+\mathrm{b})(\mathrm{a}+\mathrm{c})(\mathrm{c}+\mathrm{d})(\mathrm{b}+\mathrm{d})}$ Nilai Chi-square hitung kemudian dibandingkan dengan nilai Chi-square tabel pada derajat bebas $=1$, pada taraf uji $1 \%$ dan 5\%. Apabila nilai Chi-square hitung > nilai Chi-square tabel, maka asosiasi bersifat nyata. Apabila nilai Chi-square hitung < nilai Chi-square tabel maka asosiasi bersifat tidak nyata (Ludwig dan Reynold 1988). Selanjutnya untuk mengetahui tingkat atau kekuatan asosiasi digunakan rumus sebagai berikut:

$$
E(a)=\frac{(a+b)(a+c)}{N}
$$

Berdasarkan rumus tersebut, maka terdapat 2 jenis asosiasi yaitu: (1) asosiasi positif, apabila nilai a > E(a) berarti pasangan jenis terjadi bersama lebih sering dari yang diharapkan (2) asosiasi negatif, apabila nilai a < $\mathrm{E}(\mathrm{a})$ berarti pasangan jenis terjadi bersama kurang sering dari yang diharapkan. Selanjutnya hasil ini diuji dengan perhitungan Indeks Ochiai (Ludwig dan Reynold 1988). $\mathrm{IO}=\frac{\mathrm{a}}{\sqrt{\mathrm{a}+\mathrm{b}} \cdot \sqrt{\mathrm{a}+\mathrm{c}}}$ Semakin mendekati 1, maka asosiasi akan semakin maksimum. Sebaliknya semakin mendekati 0 , maka asosiasi akan semakin minimum bahkan tidak ada hubungan.

\section{HASIL DAN PEMBAHASAN}

\section{Jumlah Spesies}

Berdasarkan pengamatan yang dilakukan di kawasan biodiversity strip PT DRT, didapatkan jumlah spesies yang berbeda pada tingkat pertumbuhan tiang dan pohon. Jumlah spesies pada tingkat tiang dan pohon pada setiap jalur di lokasi penelitian dapat dilihat pada Tabel 2.

Berdasarkan Tabel 2 jumlah spesies tingkat tiang lebih sedikit dibandingkan tingkat pohon. Jumlah spesies tebanyak pada tingkat tiang terdapat pada jalur $\mathrm{V}$ yaitu 9 spesies, sedangkan jumlah spesies terbanyak pada tingkat pohon terbanyak terdapat pada jalur IV yaitu 20 spesies. Jumlah spesies paling sedikit tingkat tiang terdapat pada jalur III yaitu 4 spesies, sedangkan jumlah spesies paling sedikit tingkat pohon terdapat pada jalur II dan VI yaitu 14 spesies. Berdasarkan hasil penelitian tersebut, banyaknya jumlah spesies tingkat pohon tidak selalu diikuti dengan banyaknya spesies pada tingkat tiang. Menurut Komara (2008) jumlah spesies pada suatu tingkat pertumbuhan tidak selalu sama dengan tingkat pertumbuhan lainnya.

\section{Kerapatan Individu}

Kerapatan adalah jumlah individu suatu spesies tumbuhan dalam suatu luasan tertentu (Kusmana 1997). Kerapatan individu tingkat pohon di lokasi penelitian dapat dilihat pada Tabel 3 .

$\underline{\text { Tabel } 2 \text { Jumlah spesies tingkat tiang dan pohon di lokasi penelitian }}$

\begin{tabular}{llllllll}
\hline & \multirow{2}{*}{ Tingkat Pertumbuhan } & \multicolumn{7}{c}{ Jalur } \\
\cline { 2 - 8 } & Tiang & I & II & III & IV & V & VI \\
\cline { 2 - 8 } Jumlah Spesies & Pohon & 8 & 7 & 4 & 6 & 9 & 8 \\
\hline
\end{tabular}

Tabel 3 Kerapatan individu tingkat pohon di lokasi penelitian

\begin{tabular}{|c|c|c|c|c|c|c|}
\hline \multirow{2}{*}{ Spesies } & \multicolumn{6}{|c|}{ Kerapatan (Ind/Ha) } \\
\hline & $\mathrm{I}$ & II & III & IV & $\mathrm{V}$ & VI \\
\hline Artocarpus teysmanii & 100 & 20 & - & - & 80 & 100 \\
\hline Myristica lowiana & 20 & 20 & - & - & 20 & - \\
\hline Campnosperma macrophylla & 20 & - & - & - & - & 20 \\
\hline Palaquium obovatum & 40 & 40 & - & 40 & 40 & 60 \\
\hline Eugenia sp. & 20 & - & - & - & 40 & 60 \\
\hline Shorea teysmanniana & 20 & - & - & 20 & 20 & - \\
\hline Carallia brachiata & 20 & 40 & - & 20 & - & - \\
\hline Urandra scorpioides & 20 & 60 & - & - & 20 & 40 \\
\hline Ilex pleiobrachiata & - & 40 & - & - & - & - \\
\hline Mangifera foetida & - & 20 & 20 & 20 & 20 & - \\
\hline Santiria griffthii & - & - & 20 & - & - & - \\
\hline Cabai-Cabai & - & - & 20 & - & - & - \\
\hline Macaranga populifolia & - & - & 40 & - & - & - \\
\hline Horsfieldia glabra & - & - & - & 40 & 20 & - \\
\hline Dillenia exelsa & - & - & - & 20 & - & - \\
\hline Lindera subumbelliflora & - & - & - & - & 60 & - \\
\hline Aglaia rubiginosa & - & - & - & - & - & 20 \\
\hline Shorea uliginosa & - & - & - & - & - & 40 \\
\hline Parastemon urophyllum & - & - & - & - & - & 20 \\
\hline Total & 260 & 320 & 100 & 160 & 320 & 360 \\
\hline
\end{tabular}


Berdasarkan Tabel 3, pada tingkat pohon kerapatan individu tertinggi jalur I dan VI adalah Eugenia sp. dengan nilai kerapatan sebesar $25 \mathrm{ind} / \mathrm{ha}$ dan $20 \mathrm{ind} / \mathrm{ha}$, kerapatan individu tertinggi jalur II, III, dan IV adalah Palaquium obovatum dengan nilai kerapatan sebesar 40 ind/ha, $30 \mathrm{ind} / \mathrm{ha}$, dan $35 \mathrm{ind} / \mathrm{ha}$. Kerapatan individu tertinggi jalur $\mathrm{V}$ adalah Camnosperma macrophylla dengan nilai kerapatan sebesar $70 \mathrm{ind} / \mathrm{ha}$. Secara total kerapatan individu tertinggi terletak pada jalur $\mathrm{V}$ dengan nilai kerapatan sebesar 270 ind/ha, sedangkan kerapatan individu terendah terletak pada jalur VI dengan nilai kerapatan sebesar 140 ind/ha. Hal tersebut menunjukkan bahwa jumlah individu tingkat pohon pada jalur $\mathrm{V}$ lebih banyak dibandingkan dengan lima jalur lainnya Kerapatan individu tingkat tiang di lokasi penelitian dapat dilihat pada Tabel 4.

Berdasarkan Tabel 4, pada tingkat tiang kerapatan individu tertinggi jalur I adalah $A$. teysmanii dengan nilai kerapatan sebesar $100 \mathrm{ind} / \mathrm{ha}$, kerapatan individu tertinggi jalur II adalah $U$. scorpioides dengan nilai kerapatan sebesar $60 \mathrm{ind} / \mathrm{ha}$, kerapatan individu tertinggi jalur III adalah $M$. populifolia dengan nilai kerapatan sebesar 40 ind/ha, kerapatan individu tertinggi jalur IV adalah $P$. obovatum dan $H$. glabra dengan nilai kerapatan sebesar 40 ind/ha, kerapatan individu tertinggi jalur $\mathrm{V}$ adalah $A$. teysmanii dengan nilai kerapatan sebesar 80 ind/ha, dan kerapatan individu tertinggi jalur VI adalah A. teysmanii dengan nilai kerapatan sebesar $100 \mathrm{ind} / \mathrm{ha}$. Secara total kerapatan individu tertinggi terletak pada jalur VI dengan nilai kerapatan sebesar 360 ind/ha, sedangkan kerapatan individu terendah terletak pada jalur III dengan nilai kerapatan sebesar 100 ind/ha. Hal tersebut menunjukkan bahwa jumlah individu tingkat tiang pada jalur VI lebih banyak dibandingkan dengan lima jalur lainnya.

\section{Struktur Tegakan}

Jumlah pohon dan struktur tegakan dapat menggambarkan tingkat ketersediaan tegakan pada setiap tingkat pertumbuhan. Gambar 2 menyajikan jumlah individu per hektar pada berbagai kelas diameter di lokasi penelitian. Berdasarkan Gambar 2, nilai kerapatan individu tertinggi pada kelas diameter 10 - 19.9 $\mathrm{cm}$ terdapat pada jalur VI yaitu sebesar $360 \mathrm{ind} / \mathrm{ha}$, sedangkan pada kelas diameter 20 - $29.9 \mathrm{~cm}, 60$ - 69.9 $\mathrm{cm}$, dan $90-99.9 \mathrm{~cm}$ nilai kerapatan individu tertinggi terletak pada jalur IV dengan nilai sebesar 125 ind/ha, 15 ind/ha, dan 5 ind/ha. Nilai kerapatan individu tertinggi pada kelas diameter $30-39.9 \mathrm{~cm}$ terdapat pada jalur $\mathrm{V}$ yaitu $135 \mathrm{ind} / \mathrm{ha}$, sedangkan nilai kerapatan individu tertinggi pada kelas diameter $40-49.9 \mathrm{~cm}$ terdapat pada jalur III dengan nilai 25 ind/ha. Jalur I dan VI memiliki

Tabel 4 Kerapatan individu tingkat tiang di lokasi penelitian

\begin{tabular}{|c|c|c|c|c|c|c|}
\hline \multirow{2}{*}{ Spesies } & \multicolumn{6}{|c|}{ Kerapatan (Ind/Ha) } \\
\hline & I & II & III & IV & $\mathrm{V}$ & VI \\
\hline Shorea uliginosa & 15 & 5 & 25 & 25 & 25 & 15 \\
\hline Palaquium obovatum & 15 & 40 & 30 & 35 & 25 & 15 \\
\hline Durio carinatus & 15 & 5 & - & 10 & 5 & 5 \\
\hline Cапиа motleyana & 10 & - & - & - & - & - \\
\hline Aglaia rubiginosa & 10 & 5 & 5 & 10 & 5 & - \\
\hline Shorea teysmanniana & 15 & - & - & 5 & - & - \\
\hline Eugenia sp. & 25 & 15 & 10 & 20 & 20 & 20 \\
\hline Horsfieldia glabra & 10 & 25 & 20 & 20 & 15 & 5 \\
\hline Mangifera foetida & 10 & 5 & 10 & 20 & 15 & 15 \\
\hline Mezzetia parviflora & 5 & - & 5 & - & 5 & 5 \\
\hline Artocarpus teysmanii & 5 & 15 & 5 & 15 & - & 15 \\
\hline Urandra scorpioides & 5 & - & 5 & - & 10 & - \\
\hline Carallia brachiata & 5 & - & 10 & 15 & - & 10 \\
\hline Alseodaphne umbelliflora & 5 & - & 5 & 5 & - & 5 \\
\hline Gonystylus bancanus & 5 & 5 & 5 & 5 & 5 & - \\
\hline Palaquium walsurifolium & - & 5 & 5 & 15 & - & - \\
\hline Parastemon urophyllum & - & 20 & 5 & 5 & 15 & 15 \\
\hline Diospyros pendula & - & 10 & - & - & - & - \\
\hline Campnosperma macrophylla & - & 5 & - & 10 & 70 & - \\
\hline Ficus retusa & - & 5 & 5 & - & - & - \\
\hline Santiria griffthii & - & - & 5 & 5 & - & - \\
\hline Vitex pinnata & - & - & 5 & - & - & - \\
\hline Lindera subumbelliflora & - & - & 5 & 5 & 25 & - \\
\hline Tetramerista glabra & - & - & - & 5 & 5 & - \\
\hline Myristica lowiana & - & - & - & 5 & - & - \\
\hline Bengku & - & - & - & 5 & - & 5 \\
\hline Calophyllum soulattri & - & - & - & - & 5 & 5 \\
\hline Cratoxylum arborescens & - & - & - & - & 5 & - \\
\hline Dillenia exelsa & - & - & - & - & 5 & - \\
\hline Palaquium xanthochymum & - & - & - & - & 10 & - \\
\hline Lilin-Lilin & - & - & - & - & - & 5 \\
\hline Total & 155 & 165 & 165 & 240 & 270 & 140 \\
\hline
\end{tabular}


nilai kerapatan individu tertinggi pada kelas diameter 50 $-59.9 \mathrm{~cm}$ dengan nilai sebesar $20 \mathrm{ind} / \mathrm{ha}$. Nilai kerapatan individu tertinggi pada kelas diameter $70-79.9 \mathrm{~cm}$ tedapat pada jalur I dengan nilai sebesar $10 \mathrm{ind} / \mathrm{ha}$, dan tidak ditemukan individu yang memiliki diameter 80 $89.9 \mathrm{~cm}$.

Permudaan yang normal pada tegakan hutan tidak seumur mempunyai rasio yang konstan antara jumlah pohon dengan penurunan kelas diameter. Bentuk yang umum dari distribusi kelas diameter mengikuti bentuk kurva eksponensial $\mathrm{J}$ terbalik, artinya semakin besar kelas diameternya maka semakin kecil kerapatannya (Dwisutono 2015). Jalur II dan III telah sesuai dengan pernyataan di atas yaitu kerapatan individu menurun seiring dengan bertambahnya kelas diameter. Jalur I, IV, $\mathrm{V}$, dan VI tidak membentuk kurva eksponensial J terbalik karena adanya gangguan pada areal tersebut seperti perambahan.

\section{Dominansi Spesies (INP)}

Berdasarkan hasil analisis vegetasi dapat diketahui Indeks Nilai Penting (INP) jenis tumbuhan tertinggi pada

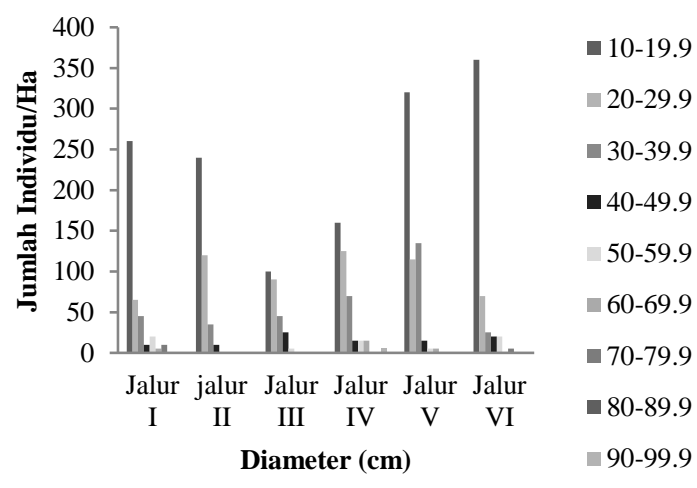

Gambar 2 Grafik struktur tegakan horizontal di lokasi penelitian berbagai tingkat pertumbuhan di lokasi penelitian. Semakin tinggi nilai INP suatu jenis maka semakin tinggi pula dominansi spesies tersebut dalam komunitas tumbuhan. Tabel 5 menyajikan nilai INP pada tingkat tiang di lokasi penelitian.

Berdasarkan Tabel 5 spesies yang mendominasi di jalur I, V, dan VI adalah A. teysmanii dengan nilai INP sebesar $100.80 \%, 61.08 \%$, dan $79.20 \%$, spesies yang mendominasi di jalur II adalah $U$. scorpioides dengan nilai INP sebesar $74.34 \%$, spesies yang mendominasi di jalur III adalah $M$. populifolia dengan nilai INP sebesar $100.81 \%$, dan spesies yang mendominasi di jalur IV adalah $P$. obovatum dengan nilai INP sebesar $77.68 \%$. Spesies A. teysmanii merupakan spesies yang mendominasi hampir pada seluruh jalur penelitian. Hal tersebut menunjukkan bahwa A. teysmanii merupakan spesies yang memiliki daya adaptasi, daya kompetisi, dan kemampuan reproduksi lebih baik dibandingkan spesies lainnya. Menurut Lempang (2016) spesies A. teysmanii merupakan spesies yang regenerasi alami dengan biji cukup mudah dan mudah tumbuh. Nilai INP tingkat pohon pada lokasi penelitian dapat dilihat pada Tabel 6 .

Berdasarkan Tabel 6 spesies yang mendominasi di jalur I adalah $S$. teysmanniana dengan nilai INP sebesar $37.69 \%$, spesies yang mendominasi di jalur II dan III adalah $P$. obovatum dengan nilai INP sebesar $59.19 \%$ dan $55.08 \%$, dan spesies yang mendominasi di jalur IV dan VI adalah $S$. uliginosa dengan nilai INP sebsar $38.81 \%$ dan $41.95 \%$, sedangkan spesies yang mendominasi pada jalur V adalah $C$. macrophylla dengan nilai INP sebesar $67.80 \%$. Spesies $P$. obovatum merupakan spesies yang mendominasi hampir pada seluruh jalur penelitian. Hal tersebut menunjukkan bahwa $P$. obovatum merupakan spesies yang memiliki daya adaptasi, daya kompetisi, dan kemampuan reproduksi lebih baik dibandingkan spesies lainnya. Menurut Purwaningsih (2006) P. obovatum merupakan jenis yang adaptif terhadap kerusakan dan banyak ditemukan di dataran rendah.

Tabel 5 Nilai INP tingkat tiang di lokasi penelitian

\begin{tabular}{lllllll}
\hline \multicolumn{1}{c}{ Spesies } & \multicolumn{7}{c}{ INP $(\%)$} \\
\cline { 2 - 7 } & \multicolumn{1}{c}{ I } & II & III & IV & V & VI \\
\hline Artocarpus teysmanii & 100.80 & 27.59 & - & - & 61.08 & 79.20 \\
Myristica lowiana & 20.16 & 26.12 & - & - & 22.78 & - \\
Campnosperma macrophylla & 24.26 & - & - & - & - & 19.05 \\
Palaquium obovatum & 49.85 & 45.53 & - & 77.68 & 37.44 & 43.25 \\
Eugenia sp. & 25.69 & - & - & - & 44.72 & 54.04 \\
Shorea teysmanniana & 26.84 & - & - & 42.67 & 23.98 & - \\
Carallia brachiata & 28.47 & 59.92 & - & 40.56 & - & - \\
Urandra scorpioides & 23.92 & 74.34 & - & - & 18.88 & 41.07 \\
Ilex pleiobrachiata & - & 40.38 & - & - & - & - \\
Mangifera foetida & - & 26.12 & 59.22 & 32.41 & 24.78 & - \\
Santiria griffthii & - & - & 69.11 & - & - & - \\
Cabai-Cabai & - & - & 70.86 & - & - & - \\
Macaranga populifolia & - & - & 100.81 & - & - & - \\
Horsfieldia glabra & - & - & - & 69.01 & 23.22 & - \\
Dillenia exelsa & - & - & - & 37.67 & - & - \\
Lindera subumbelliflora & - & - & - & - & 43.13 & - \\
Aglaia rubiginosa & - & - & - & - & - & 16.81 \\
Shorea uliginosa & - & - & - & - & - & 25.53 \\
Parastemon urophyllum & - & - & - & - & - & 21.05 \\
\hline
\end{tabular}




\section{Luas Bidang Dasar (LBDS)}

Luas Bidang Dasar (LBDS) merupakan parameter yang menggambarkan kerapatan individu dalam suatu tegakan pada luasan tertentu. LBDS tingkat tiang dan pohon di lokasi penelitian dapat dilihat pada Gambar 3.

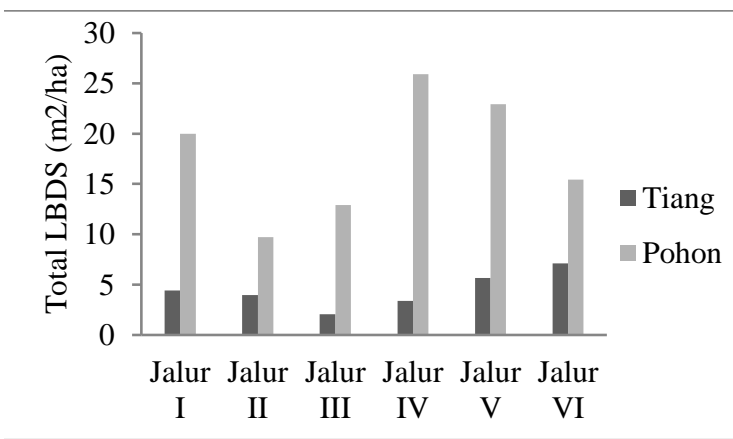

Gambar 3 Grafik LBDS tegakan di lokasi penelitian.
Berdasarkan Gambar 3 LBDS tingkat tiang tertinggi terletak pada jalur VI, sedangkan LBDS tingkat tiang terendah terletak pada jalur III. Hal tersebut dikarenakan jumlah individu yang ditemukan pada jalur VI lebih banyak dari jalur lainnya dan memiliki diameter yang besar, sedangkan pada jalur III jumlah individu yang ditemukan paling sedikit diantara jalur lainnya sehingga nilai total LBDS nya juga rendah. LBDS tingkat pohon tertinggi terletak pada jalur IV, sedangkan LBDS tingkat pohon terendah terletak pada jalur II. Hal tersebut dikarenakan pohon yang terdapat di jalur IV memiliki diameter yang besar, sedangkan pada jalur II diameter yang ditemukan kecil yaitu tidak ditemukan pohon dengan diameter $>50 \mathrm{~cm}$.

\section{Asosiasi Gonystylus bancanus dengan Jenis Dominan}

Asosiasi adalah hubungan ketertarikan untuk tumbuh bersama antara dua spesies, yang dapat bersifat positif atau negatif. Hasil perhitungan uji asosiasi antara G. bancanus dengan kelima jenis dominan pada tingkat tiang di IUPHHK-HA PT DRT dapat dilihat pada Tabel 7.

Tabel 6 Nilai INP tingkat pohon di lokasi penelitian

\begin{tabular}{|c|c|c|c|c|c|c|}
\hline \multirow{2}{*}{ Spesies } & \multicolumn{6}{|c|}{ INP $(\%)$} \\
\hline & $\mathrm{I}$ & II & III & IV & $\mathrm{V}$ & VI \\
\hline Shorea uliginosa & 35.73 & 14.65 & 45.28 & 38.81 & 34.97 & 41.95 \\
\hline Palaquium obovatum & 22.30 & 59.19 & 55.08 & 31.83 & 25.99 & 30.82 \\
\hline Durio carinatus & 33.79 & 14.43 & - & 18.05 & 5.60 & 16.94 \\
\hline Cапиа motleyana & 20.26 & & - & & & - \\
\hline Aglaia rubiginosa & 17.32 & 10.81 & 7.95 & 14.48 & 5.54 & - \\
\hline Shorea teysmanniana & 37.69 & & - & 5.17 & - & - \\
\hline Eugenia sp. & 35.32 & 30.60 & 12.05 & 24.40 & 18.27 & 31.84 \\
\hline Horsfieldia glabra & 17.02 & 37.48 & 34.83 & 32.48 & 11.29 & 14.22 \\
\hline Mangifera foetida & 18.29 & 10.51 & 18.14 & 20.72 & 17.12 & 26.83 \\
\hline Mezzetia parviflora & 8.55 & - & 12.83 & - & 5.66 & 11.35 \\
\hline Artocarpus teysmanii & 7.96 & 27.95 & 9.10 & - & - & 20.34 \\
\hline Urandra scorpioides & 8.01 & - & 7.95 & - & 12.27 & - \\
\hline Carallia brachiata & 8.13 & - & 15.82 & 18.76 & - & 20.54 \\
\hline $\begin{array}{l}\text { Alseodaphne } \\
\text { umbelliflora }\end{array}$ & 11.05 & - & 12.66 & 5.42 & - & - \\
\hline Gonystylus bancanus & 18.58 & 10.90 & 7.94 & 10.33 & 6.52 & - \\
\hline $\begin{array}{l}\text { Palaquium } \\
\text { walsurifolium }\end{array}$ & - & 11.35 & 16.61 & 16.92 & - & - \\
\hline Parastemon urophyllum & - & 38.96 & 7.95 & 6.34 & 18.28 & 33.03 \\
\hline Diospyros pendula & - & 14.14 & - & - & - & - \\
\hline $\begin{array}{l}\text { Campnosperma } \\
\text { macrophylla }\end{array}$ & - & 9.43 & - & 11.86 & 67.80 & - \\
\hline Ficus retusa & - & 9.56 & 9.82 & - & - & - \\
\hline Santiria griffthii & - & - & 7.83 & - & - & - \\
\hline Vitex pinnata & - & - & 8.25 & - & - & - \\
\hline Lindera subumbelliflora & - & - & 9.94 & 5.61 & 28.87 & - \\
\hline Tetramerista glabra & - & - & - & 7.94 & 6.59 & - \\
\hline Myristica lowiana & - & - & - & 5.14 & - & - \\
\hline Bengku & - & - & - & 5.14 & - & 9.24 \\
\hline Calophyllum soulattri & - & - & - & - & 6.75 & 21.52 \\
\hline Cratoxylum arborescens & - & - & - & - & 6.16 & - \\
\hline Dillenia exelsa & - & - & - & - & 7.35 & - \\
\hline Palaquium & - & - & - & - & 14.96 & - \\
\hline $\begin{array}{l}\text { xanthochymum } \\
\text { Lilin-Lilin }\end{array}$ & - & - & - & - & - & 9.16 \\
\hline
\end{tabular}


Ada atau tidaknya asosiasi harus didasarkan pada perbandingan antara $\mathrm{X}^{2}$ hitung dengan $\mathrm{X}^{2}$ tabel. Jenis $G$. bancanus tidak ada yang berasosiasi nyata dengan kelima jenis dominan pada tingkat tiang karena semua nilai $\mathrm{X}^{2}$ hitungnya lebih kecil dari $\mathrm{X}^{2}$ tabel baik pada $\alpha=1 \%$ (6.63) maupun $\alpha=5 \%$ (3.84). Schluter (1984) dalam Mayasari, Kinho, dan Suryawan (2012) menyatakan bahwa asosiasi tidak jelas atau tidak ada hubungan mungkin dihasilkan oleh penyeimbangan kekuatan positif dan negatif. Tidak adanya asosiasi pada tingkat tiang disebabkan oleh kelimpahan jenis G. bancanus di IUPHHK-HA PT DRT relatif lebih rendah dibandingkan dengan jenis yang lain, bahkan jenis $G$. bancanus tidak ditemukan pada tingkat tiang di plot penelitian. Meskipun tidak ada jenis yang berasoiasi nyata dengan $G$. bancanus, tetapi $G$. bancanus dapat dikatakan memiliki tipe asosiasi positif dengan jenis $P$. obovatum, $U$. scorpioides, dan $C$. brachiata.

Berdasarkan pengamatan, pasangan jenis $G$. bancanus dengan $P$. obovatum serta pasangan jenis $G$. bancanus dengan $U$. scorpioides ditemukan bersamasama dalam 2 plot, sedangkan pasangan jenis $G$. bancanus dengan $C$. brachiata ditemukan bersama-sama dalam 1 plot. Hal ini menunjukkan bahwa meskipun tidak ada hubungan antara $G$. bancanus dengan kelima jenis dominan tersebut, tetapi mereka masih dapat hidup secara bersama-sama dan tidak saling mengganggu satu sama lainnya. Menurut Barbour et al (1999) dalam Fajri dan Ngatiman (2012), hal tersebut menunjukkan bahwa selain pengaruh interaksi pada suatu komunitas, tiap tumbuhan saling memberi tempat hidup pada suatu area dan habitat yang sama. G. bancanus berasosiasi negatif dengan $A$. teysmanii dan Eugenia sp. Berdasarkan pengamatan pasangan jenis $G$. bancanus dengan $A$. teysmanii ditemukan bersama-sama dalam 1 plot, sedangkan G. bancanus dan Eugenia sp. tidak pernah ditemukan bersama dalam plot yang sama. Hal tersebut menunjukkan bahwa $G$. bancanus bersaing dengan $A$. teysmanii dan Eugenia sp. dalam hidupnya. Menurut Odum (1993) persaingan tersebut dapat searah maupun dua arah (timbal balik). Penghitungan indeks asosiasi dilakukan untuk mengetahui seberapa besar derajat asosiasi antara $G$. bancanus dengan kelima jenis dominan tingkat tiang di IUPHHK-HA PT DRT serta diperlukan untuk menguatkan hasil perhitungan dari tabel kontingensi $2 \times 2$. Hasil perhitungan indeks asosiasi antara G. bancanus dengan jenis dominan tingkat tiang dapat dilihat pada Tabel 8 .

Berdasarkan tabel 8 umumnya pasangan jenis yang diamati mempunyai nilai indeks asosiasi yang rendah $(60 \%)$ dan sangat rendah (40\%) dan sama sekali tidak ada pasangan yang memiliki nilai indeks asosiasi yang sangat tinggi dan tinggi. Pasangan jenis yang memiliki nilai indeks asosiasi rendah adalah pasangan jenis $G$. bancanus dengan $C$. brachiata dan $P$. obovatum, sedangkan pasangan jenis yang memiliki nilai indeks asosiasi sangat rendah adalah pasangan jenis $G$. bancanus dengan A. teysmanii, U. scorpioides, dan Eugenia sp.

Hasil perhitungan uji asosiasi antara G. bancanus dengan jenis dominan pada tingkat pohon di IUPHHKHA PT DRT dapat dilihat pada Tabel 9. Berdasarkan Tabel 9 Jenis $G$. bancanus tidak ada yang berasosiasi nyata dengan jenis dominan pada tingkat pohon karena semua nilai $\mathrm{X}^{2}$ hitungnya lebih kecil dari $\mathrm{X}^{2}$ tabel baik pada $\alpha=1 \%$ (6.63) maupun $\alpha=5 \%$ (3.84). Tidak adanya asosiasi pada tingkat pohon disebabkan oleh kelimpahan jenis G. bancanus di IUPHHK-HA PT DRT relatif lebih rendah dibandingkan dengan jenis yang lain yaitu hanya ditemukan 5 individu G. bancanus di lokasi penelitian. Meskipun tidak ada jenis yang berasosiasi nyata dengan

Tabel 7 Hasil perhitungan asosiasi antara G. bancanus dengan jenis dominan tingkat tiang dilokasi penelitian

\begin{tabular}{|c|c|c|c|c|c|c|c|}
\hline \multirow[t]{2}{*}{ Jenis } & \multirow[t]{2}{*}{$\mathrm{X}^{2}$ Hitung } & \multirow[t]{2}{*}{$\mathrm{a}$} & \multirow[t]{2}{*}{$\mathrm{E}(\mathrm{a})$} & \multicolumn{2}{|c|}{ Asosiasi } & \multirow{2}{*}{$\begin{array}{c}\text { Tipe } \\
\text { Asosiasi }\end{array}$} & \multirow{2}{*}{$\begin{array}{c}\text { Nilai } \\
\text { Indeks } \\
\text { Asosias }\end{array}$} \\
\hline & & & & $\alpha=1 \%$ & $\alpha=5 \%$ & & \\
\hline $\begin{array}{lr}G . & \text { bancanus } \\
\text { dengan } & \text { A. } \\
\text { teysmanii }\end{array}$ & 0.35 & 1 & 1.67 & TD & TD & - & 0.14 \\
\hline $\begin{array}{lr}G . & \text { bancanus } \\
\text { dengan } & \text { P.obovatum }\end{array}$ & 0.06 & 2 & 1.17 & TD & TD & + & 0.34 \\
\hline $\begin{array}{lr}G . & \text { bancanus } \\
\text { dengan } & U . \\
\text { scorpioides } & \end{array}$ & 0.05 & 1 & 0.67 & TD & TD & + & 0.22 \\
\hline $\begin{array}{l}\text { G.bancanus dengan } \\
\text { Eugenia } \text { sp. }\end{array}$ & 0.19 & 0 & 0.83 & TD & TD & - & 0 \\
\hline $\begin{array}{l}\text { G.bancanus dengan } \\
\text { C. brachiata }\end{array}$ & 0.11 & 2 & 1.17 & TD & TD & + & 0.34 \\
\hline
\end{tabular}

Keterangan: $\mathrm{TD}=$ Tidak Ditemukan, $\mathrm{D}=$ Ditemukan

Tabel 8 Indeks asosiasi antara G. bancanus dengan jenis dominan tingkat tiang di lokasi penelitian

\begin{tabular}{lllll}
\hline No & Indeks Asosiasi & Keterangan & Jumlah Kombinasi & Presentase $(\%)$ \\
\hline 1 & $1.00-0.75$ & Sangat tinggi & 0 & 0 \\
2 & $0.74-0.49$ & Tinggi & 0 & 0 \\
3 & $0.48-0.23$ & Rendah & 2 & 40 \\
4 & $<0.22$ & Sangat rendah & 3 & 60 \\
\hline \multicolumn{5}{r}{} \\
\hline
\end{tabular}


G.bancanus, tetapi G. bancanus dapat dikatakan memiliki tipe asosiasi positif dengan jenis $S$. uliginosa, $P$. obovatum, Eugenia sp., dan H. glabra. Berdasarkan pengamatan, pasangan jenis $G$. bancanus dengan $P$. obovatum serta pasangan jenis $G$. bancanus dengan $H$. glabra ditemukan bersama-sama dalam 4 plot, sedangkan pasangan jenis $G$. bancanus dengan $S$. uliginosa serta pasangan jenis $G$. bancanus dengan Eugenia sp., ditemukan bersama-sama dalam 3 plot. Jenis G. bancanus berasosiasi positif dengan Eugenia sp. pada tingkat pohon, dan berasosiasi negatif ketika Eugenia sp. berada pada tingkat tiang. Hal tersebut menunjukkan bahwa $G$. bancanus hanya dapat hidup bersama dengan Eugenia sp. pada tingkat pohon saja, tetapi tidak dapat hidup bersama saat masih berada pada tingkat tiang, pancang, dan semai.

Jenis $G$. bancanus berasosiasi negatif dengan $A$. rubiginosa dan $M$. foetida. Berdasarkan pengamatan pasangan jenis $G$. bancanus dengan $A$. rubiginosa ditemukan bersama-sama dalam 1 plot, sedangkan pasangan jenis $G$. bancanus dengan $M$. foetida ditemukan bersama-sama dalam 2 plot. Hasil perhitungan indeks asosiasi antara $G$. bancanus dengan jenis dominan tingkat pohon dapat dilihat pada Tabel 10.

Berdasarkan tabel 10 umumnya pasangan jenis yang diamati memiliki nilai indeks asosiasi yang rendah $(66.67 \%)$. Tetapi juga terdapat pasangan jenis yang memiliki nilai indeks asosiasi yang tinggi $(16.67 \%)$ yaitu pasangan jenis $G$. bancanus dengan $H$. glabra, dan terdapat jugan pasangan jenis yang memiliki nilai indeks asosiasi yang sangat rendah $(16.67 \%)$ yaitu pasangan jenis $G$. bancanus dengan A. rubiginosa. Pasangan jenis yang memiliki nilai indeks asosiasi rendah adalah jenis G. bancanus dengan S. uliginosa, P. obovatum, Eugenia sp., dan M. foetida.

\section{SIMPULAN DAN SARAN}

\section{Simpulan}

Berdasarkan hasil penelitian, tidak ada jenis dominan yang berasosiasi nyata dengan $G$. bancanus pada tingkat tiang dan pohon di IUPHHK-HA PT DRT. Meskipun tidak terdapat jenis pada tingkat tiang yang berasosiasi nyata dengan $G$. bancanus tetapi dapat dikatakan bahwa $G$. bancanus berasosiasi positif dengan P. obovatum, U. scorpioides, dan C. brachiata, serta berasosiasi negatif dengan A. teysmanii dan Eugenia sp. Nilai indeks asosiasi $G$. bancanus dengan $C$. brachiata dan $P$. obovatum tergolong rendah, sedangkan nilai indeks asosiasi $G$. bancanus dengan A. teysmanii, $U$. scorpioides, dan Eugenia sp. tergolong sangat rendah. Pada tingkat pohon $G$. bancanus dapat dikatakan berasosiasi positif dengan S. uliginosa, P. obovatum, Eugenia sp., dan H. glabra, serta berasosiasi negatif dengan $A$. rubiginosa dan $M$. foetida. Nilai indeks asosiasi $G$. bancanus dengan $H$. glabra tergolong tinggi, sedangkan nilai indeks asosiasi $G$. bancanus dengan $S$. uliginosa, P. obovatum, Eugenia sp., dan M. foetida tergolong rendah. Nilai indeks asosiasi $G$. bancanus dengan $A$. rubiginosa tergolong sangat rendah.

\section{Saran}

Berdasarkan hasil penelitian, perlu dilakukan penanaman ramin di lapang karena jumlah ramin semakin sedikit bahkan pada tingkat tiang tidak ditemukan jenis ramin pada lokasi penelitian. Penanaman ramin di lapang tidak harus memperhatikan vegetasi yang terdapat di sekitarnya karena ramin tidak berasosiasi nyata dengan jenis-jenis dominan di IUPHHK-HA PT Diamond Raya Timber.

Tabel 9 Hasil perhitungan asosiasi antara G. bancanus dengan jenis dominan tingkat pohon di lokasi penelitian

\begin{tabular}{|c|c|c|c|c|c|c|c|}
\hline \multirow[t]{2}{*}{ Jenis } & \multirow[t]{2}{*}{$\mathrm{X}^{2}$ Hitung } & \multirow[t]{2}{*}{$\mathrm{a}$} & \multirow[t]{2}{*}{$\mathrm{E}(\mathrm{a})$} & \multicolumn{2}{|c|}{ Asosiasi } & \multirow{2}{*}{$\begin{array}{l}\text { Tipe } \\
\text { Asosiasi }\end{array}$} & \multirow{2}{*}{$\begin{array}{l}\text { Nilai Indeks } \\
\text { Asosiasi }\end{array}$} \\
\hline & & & & $\alpha=1 \%$ & $\alpha=5 \%$ & & \\
\hline $\begin{array}{l}\text { G.bancanus dengan } \\
\text { S.uliginosa }\end{array}$ & 0.05 & 3 & 3.00 & TD & TD & + & 0.33 \\
\hline $\begin{array}{l}\text { G.bancanus dengan } \\
\text { P.obovatum }\end{array}$ & 0.01 & 4 & 3.33 & TD & TD & + & 0.40 \\
\hline $\begin{array}{l}\text { G. bancanus dengan } \\
\text { A. rubiginosa }\end{array}$ & 0.00004 & 1 & 1.17 & TD & TD & - & 0.17 \\
\hline $\begin{array}{l}\text { G.bancanus dengan } \\
\text { Eugenia sp. }\end{array}$ & 0.000001 & 3 & 2.17 & TD & TD & + & 0.37 \\
\hline $\begin{array}{l}\text { G.bancanus dengan } \\
\text { H.glabra }\end{array}$ & 0.0001 & 4 & 2.17 & TD & TD & + & 0.49 \\
\hline $\begin{array}{l}\text { G. bancanus dengan } \\
M \text {. foetida }\end{array}$ & 0.0002 & 2 & 2.17 & TD & $\mathrm{TD}$ & - & 0.25 \\
\hline
\end{tabular}

Keterangan: $\mathrm{TD}=$ Tidak Ditemukan

Tabel 10 Indeks asosiasi antara G. bancanus dengan jenis-jenis dominan tingkat pohon di lokasi penelitian

\begin{tabular}{lllll}
\hline No & Indeks Asosiasi & Keterangan & Jumlah Kombinasi & Presentase $(\%)$ \\
\hline 1 & $1.00-0.75$ & Sangat tinggi & 0 & 0 \\
2 & $0.74-0.49$ & Tinggi & 1 & 16.67 \\
3 & $0.48-0.23$ & Rendah & 4 & 66.67 \\
4 & $<0.22$ & Sangat rendah & 1 & 16.67 \\
\hline
\end{tabular}




\section{DAFTAR PUSTAKA}

[Asian Wetland dan Direktorat Jenderal PHPA]. 1993. Warta Konservasi Lahan Basah Vol 2 No 2. Bogor (ID): Asian Wetland dan Direktorat Jenderal PHPA.

Fajri M dan Ngatiman. 2012. Analisis vegetasi dan asosiasi jenis pada habitat Parashorea malaanonan Merr. Info Teknis Dipterokarpa 5(01):13-23.

Haryanto. 1989. Studi pendahuluan struktur vegetasi hutan gambut di Pulau Padang, Propinsi Riau. Media Konservasi 2(04): 29-43.

Heriyanto N M dan Garsetiasih R. 2006. Ekologi dan potensi ramin (Gonystylus bancanus Kurz.) di kelompok hutan Sungai Tuan-Sungai Suruk, Kalimantan Barat. Buletin Plasma Nutfah 12(01): 24-29.

Indriyanto. 2006. Ekologi Hutan. Jakarta (ID): Bumi Aksara.

Istomo. 2005. Evaluasi penanaman (Gonystylus spp) di Indonesia: kendala dan program kegiatan dalam pembangunan hutan tanaman ramin. Di dalam: Konservasi dan Pembangunan Hutan Ramin di Indonesia Melalui Regulasi Perdagangan dan Pemacuan Alih Teknologi Konservasi, Penanaman dan Teknik Silvikultur; 2005 Sep 28; Bogor, Indonesia. Bogor (ID): hal 79-81.

Kurniawan A, Undaharta N E, dan Pendit I M R. 2008. Asosiasi jenis pohon dominan di hutan dataran rendah Cagar Alam Tangkoko, Bitung, Sulawesi Utara. Jurnal Biodiversitas 09(03): 199-203.

Komara C. 2008. Komposisi jenis dan struktur tegakan Shorea balangeran (Korth.) Burck., Hopea bancana (Boerl.) Van Slooten dan Coumarouna odorata Anbl. Di hutan penelitian Dramaga Bogor [Skripsi]. Bogor (ID): Institut Pertanian Bogor.

Kusmana C. 1997. Metode Survey Vegetasi. Bogor (ID): IPB Press.

Lempang M. 2016. Sifat dasar dan potensi kegunaan kayu saling-saling. Jurnal Penelitian Kehutanan Wallacea 5(01): 7.

Ludwig JA, Reynolds JF. 1988. Statistical Ecology. New York (USA): Edward Arnold.

Mayasari A, Kinho J, dan Suryawan A. 2012. Asosiasi eboni (Diospyros spp.) dengan jenis-jenis pohon dominan di Cagar Alam Tangkoko Sulawesi Utara. Jurnal Info BPK 02(01): 55-72.
Meyer HA, Recknagel AB, Stevenson DD, Bartoo RA. 1961. Forest Management. Ed ke-2. New York (USA): The Ronald Press Company.

Mofhar R. 2012. Struktur tegakan dan sebaran jenis ramin dan meranti di hutan rawa gambut (studi kasus PT. Diamond Raya Timber dan PT. Riau Andalan Pulp and Paper, Propinsi Riau) [Skripsi]. Bogor (ID): Institut Pertanian Bogor.

Muin A. 2009. Teknologi Penanaman Ramin (Gonystylus bancanus Miq. Kurz) pada Areal Bekas Tebangan. Pontianak (ID): Untan Press.

Muin A, Setiadi Y, Budi SW, Mansur I, Suhendang E, Sabiham S. 2006. Studi intensitas cahaya dan cendawan mikoriza arbuskula pada permudaan alam ramin (Gonystylus bancanus (Miq.) Kurz). Jurnal Manajemen Hutan Tropika 12(03):72-80.

Odum E. 1993. Dasar-Dasar Ekologi. Samingan T, penerjemah. Yogyakarta (ID): Gadjah Mada University Press. Terjemahan dari: Fundamentalis of Ecology.

Partomihardjo T 2006. Populasi ramin (Gmystylus bancanus (Miq.) Kurz) di hutan alam:regenerasi, pertumbuhan, dan produksi. Di dalam: Policy Option on The Conservation and Utilization of Ramin; 2006 Feb 22; Bogor, Indonesia. Bogor (ID): hal 40-54.

Prasetyo D. 2006. Kajian komposisi dan struktur tegakan serta pertumbuhan jenis-jenis komersial, khususnya jenis ramin (Gonystylus bancanus (Miq.) Kurz.) di hutan rawa gambut IUPHHK PT. Diamond Raya Timber, Propinsi Riau [Skripsi]. Bogor (ID): Institut Pertanian Bogor.

Purwaningsih. 2006. Analisis vegetasi hutan pada beberapa ketinggian tempat di Bukit Wawouwai, Pulau Wawonii, Sulawesi Tenggara. Boidiversitas 7(01): 49-53.

Rochmayanto Y, Darusman D, Rusolono T, editor. 2013. Hutan Rawa Gambut dan HTI Pulp dalam Bingkai REDD+. Bogor (ID): FORDA Press.

Sondang M. 1995. Penentuan biomassa di atas tanah jenis ramin (Gonystylus bancanus (Miq.) Kurz) di HPH PT. Diamond Raya Timber Propinsi Dati I Riau [Skripsi]. Bogor (ID): Institut Pertanian Bogor.

Soerianegara I, Indrawan A. 2002. Ekologi Hutan Indonesia. Bogor (ID): Institut Pertanian Bogor.

Suhendang E. 2002. Pengantar Ilmu Kehutanan. Bogor (ID): IPB Press. 